data of acid detergent lignine (ADL) content, « in vitro » and « in vivo " digestibility of woody species in order to predict the « in vivo " digestibility of Atriplex nummularia and Acacia salicina.

The " in vivo » digestibility of dry matter (DMD) and organic matter (OMD) of Atriplex nummularia was $57.4 \%$ and $50.4 \%$, respectively. For Acacia salicina, these values were $46.8 \%$ and $48.0 \%$. The " in vitro " values (using ruminal fluid) for those parameters were $57.5 \%$ and $44.9 \%$ (Atriplex) and $54.1 \%$ and $46.0 \%$ (Acacia). In relation with enzymatic solubility (DMS and OMS), the values were $60.6 \%$ and $49.2 \%$ (Atriplex) and $52.1 \%$ and $46.5 \%$ (Acacia).

The simple regressions derived were :

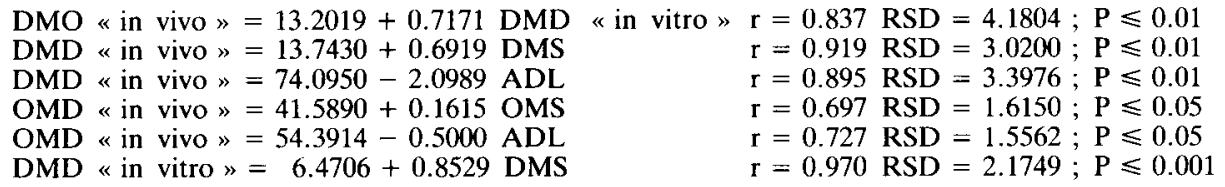

The results obtained show that Atriplex nummularia and Acacia salicina are interesting species to introduce in arid areas for goat feeding.

The provisional regression equations obtained seem to give a correct estimation of the digestibility of the studied species taking into account the high values of the correlation coefficients, levels of significance and the low standard deviations obtained.

Key words : Nutritive value, Atriplex nummularia, Acacia salicina, goat, digestibility.

\title{
Digestibility of holm oak (Quercus ilex) fresh foliage in goats : first results
}

\section{MEURET}

\section{INRA-S.A.D., Unité d'Ecodéveloppement, Domaine Saint-Paul, 84140 Montfavet (France)}

In Southern France, woodlands are dramatically exposed to fire. Thus, the Forest Managers have planned to reintroduce experimentally some goat herds in the forests to make them participate to the undergrowth-clearing operations. As part of this program, we studied the nutritive value of the main fibrous feeds and their improvement by a suitable complementary feeding. A first trial was made with holm oak (Quercus ilex). Six two-year old goats of the local breed, with a mean live weight of $25 \mathrm{~kg}$, dried since one month and well used to browsing on rangelands were used. Animals were placed in confortable digestibility cages allowing the separate collection of faeces and urine. Cages were specially equipped for distribution of freshly cut branches of trees and shrubs.

From March 19th to April 16th 1986, goats received each day continuously from $10: 30$ a.m. to $07: 00$ p.m. fresh branches cut less than 2 hours before. In addition, animals received each evening a minimum protein supplement of $0.81 \mathrm{~g} \mathrm{DM} / \mathrm{kg} \mathrm{LW}{ }^{0.75}$ soybean meal, corresponding to the protein contribution of the herbaceous species eated on the range. This foraging method allowed us to use the "browsed-class " technique to estimate the intake quality, as a function of the branch type and the rate of consumption of the potential edible matter (P.E.M.) on each branch. Every day, at intervals, many samples of leaves and stems were collected for dry matter determination and chemical analysis.

Results of animal weighings showed a steady increase in the live weight $(100 \mathrm{~g} \mathrm{LW} /$ day) from the 5th day of cages entering to the coming out, indicating real ad libitum feeding conditions. Similar individual choices between branch types and comparable rates of consumption (with a high frequency of the $90 \%$ rate) led to very steady plant part proportions in the individual diets (leaveto-stem ratio $=5.96 \pm 0.13$ ). This composition of the ingested matter was very close to the holm oak mean bite composition recorded on the range with a $10 \mathrm{~A} / \mathrm{ha}$ day stocking density. The chemical composition of the oak diet was $96.3 \%$ Organic Matter, $30.5 \%$ Crude Fibre and $8.3 \%$ Crude Protein. This foraging method with fresh branches led to a high and steady level of intake : $90.1 \pm 3.5 \mathrm{~g} \mathrm{DM} / \mathrm{kg} \mathrm{LW}$. 5 day for a 18 -day period. For this period the following apparent digestibilities were obtained : 
- Organic Matter : $47.8 \pm 1.0 \%$ dry matter ;

- Crude Fibre (WEENDE) : $24.0 \pm 2.0 \%$;

- Crude Protein : $53.1 \pm 2.1 \%$.

The total water intake level was very low : $1140 \mathrm{~g}$ water $/ \mathrm{kg}$ DM intake.

At this time (Oct. 86), all the experimental results were not analysed and thus we are not able to propose satisfactory conclusions. Nevertheless, we must say that, in our specific conditions, browsing behaviour in cages is very close to that recorded on the range with a moderate stocking density. The first estimates of apparent digestibilities show that fibres were very poorly used and point out to a digestibility of oak proteins better than expected. In future studies, we will test mixed diets in cages and on the range, in order to define the best nitrogen/energy ratio and quality to improve this fibre utilization.

Key words: Digestibility, Quercus ilex, goat, rangeland.

\title{
Intake and digestibility of kermes oak (Quercus coccifera) browse in goats, as affected by phenological stage and supplementation
}

\author{
A.S. NASTIS \\ Range Sci. Lab. 236, Aristotelion University, 54006 Thessaloniki (Greece)
}

Intake and digestibility of kermes oak browse (Quercus coccifera) was tested in goats in digestion trials during spring, summer, fall and winter. Additionally, the effect of sugar beet pulp $\left(14 \mathrm{~g} / \mathrm{BW}^{.75} /\right.$ animal/day) and soybean meal $\left(25 \mathrm{~g} / \mathrm{BW}^{.75} /\right.$ animal/day) on intake and digestibility were tested, during the winter season. For comparative purposes a digestion trial with good quality alfalfa was conducted. Forage on offer was presented as fresh branches at amounts over three times the maximum intake observed during the 10-day preliminary period preceding each trial.

Crude protein content of DM consumed did not vary significantly among seasons. It was $7.8 \%$ during the spring period, $6.5 \%$ during summer, $7.2 \%$ during fall and $7.1 \%$ during winter. No significant differences were found in NDF, ADF and total energy content ranging from 51.2 to $54.6 \%, 37.0$ to $37.9 \%, 4.8$ to $4.9 \mathrm{Kcal} / \mathrm{g}$ respectively. A significant increase was found only in lignin content from $13.3 \%$ in spring to $17.6 \%$ in summer.

Intake of spring collection kermes oak $79 \mathrm{~g} / \mathrm{kg} \mathrm{BW}^{75}$ was significantly higher than that of oak collected during the other seasons in which intake ranged from 51 to $59 \mathrm{~g}^{\prime} \mathrm{kg} \mathrm{BW}^{75}$. Intake by goats consuming winter collection oak was increased only when animals were supplemented with soybean meal. However, when kermes oak was considered alone no significantly increased intake was observed. Intake of plain oak all seasons but Spring was very low and corresponded to less than $45 \%$ of their potential intake capacity when compared to alfalfa hay intake (129 $\mathrm{g} / \mathrm{kg}$ $\mathrm{BW}^{.75}$ ).

Apparent DM digestibility of spring oak $(70 \%)$ was significantly higher $(\mathrm{P} \leqslant 0.05)$ than that $(53-56 \%)$ of oak collected during the other phenological stages. There was no significant difference between oak collected during summer, fall or winter. This was partially a result of the selective grazing of the animals. The overall digestibility when supplemented with sugar beet pulp $(54 \%)$ or soybean meal $(55 \%)$ was not significantly affected. In vitro digestibility determined by the Tilley and TerRY (1963) method using inoculum from goats browsing fresh oak underestimated in vivo findings by 10 units for mature oak foliage and by 20 units for the immature foliage.

Nitrogen digestibility was significantly higher $(66 \%)$ for the spring foliage when compared to the remaining oak diets $(42-46 \%)$. Similar results have been found for the apparently digested energy. Nitrogen content in spring oak compared to tabulated values was adequate for maintenance while it was below the requirements for milk production. Nitrogen content of oak from the remaining seasons was insufficient even for maintenance. Digestible energy content per $\mathrm{kg}$ of feed (over $2.4 \mathrm{Mcal} / \mathrm{kg}$ ) was sufficient for maintenance but insufficient for lactation all seasons but spring. However, digestible energy actually consumed was well below the maintenance requirements due to the low level of intake and its low digestibility.

Key words : Quercus coccifera, goat, digestibility, intake. 